\title{
The Influence of Exercise Model Using Video Media on Swimming Grabstart Skills for Deaf Children
}

\author{
Anggri Dwi Nata ${ }^{1}$, Hilda Oktri Yeni ${ }^{1}$, Fadli Surahman ${ }^{1}$, Rusdi ${ }^{2}$ \\ ${ }^{1}$ Physical Education, Health and Recreation Department, Universitas Karimun, Jl. Raya Komp. \\ Timah, Tlk. Uma, Tebing, Kabupaten Karimun, Kepulauan Riau \\ ${ }^{2}$ Physical Education, Health and Recreation Department, IKIP Pontianak, Jl. Ampera No.88, \\ Sungai Jawi, Kec. Pontianak Kota, Kota Pontianak, Kalimantan Barat \\ *Corresponding author email: anggrybirds45@ gmail.com
}

\begin{abstract}
The main problem of the research is the low mastery of the skills to start swimming deaf children. The purpose of this study was to determine the effect of the exercise model using video media on swimming grabstart skills in deaf children. Subjects were 40 deaf children consisting of 20 experimental groups and 20 control groups. Data collection was carried out by conducting initial tests to grabstart swimming skills, practice (training models using video media) and final tests of grabstart swimming skills. Data analysis and hypothesis testing using comparative analysis techniques using the Dependent sample t-test, namely Paired sample t-test and Independent sample t-test, namely t-Test: Two-Sample Assuming Equal Variances with a significant level $\alpha=0.05$. Based on the results of the study it can be concluded that: 1) There is an effect of the exercise model using video media on swimming grabstart skills in deaf children from an average value of 51.05 to 64.94 with $\mathrm{T}_{\text {count }}=14.93 \mathrm{>}$ $\left.\mathrm{T}_{\text {table }}=2.10,2\right)$ There is an influence of the control group on swimming grabstart skills in deaf children from an average value of 47.89 to 52.69 with $\mathrm{T}_{\text {count }}=4.47>\mathrm{T}_{\text {table }}=2.10 .3$ ) There is a difference between the effect of the exercise model using video media with a control group with $\mathrm{T}_{\text {count }}=3.82>\mathrm{T}_{\text {table }}=2.02$.
\end{abstract}

Keywords: training model, video media, grabstart swimming.

\section{INTRODUCTION}

Sports are all systematic activities to encourage, foster, and develop physical, spiritual, and social potential (Ministry of Youth and Sports of the Republic of Indonesia Law number 3 , 2005). In this case sport is an activity organized systematically in order to encourage, foster and develop human resources both physically, spiritually and social relationships with other humans. exercise has many benefits for the health and fitness of the human body. The importance of sport for humans can be analogous to machines that are not used / driven. Over time, then the parts of the machine will be damaged because it does not move / work to be trained. Likewise with the human body, if lack of movement, the body will become problematic and feel sick. By exercising, not only the muscles are trained, the circulation of blood and oxygen in the body becomes smooth so that the body's metabolism is optimal. Besides the brain as a nerve center will work for the better. 
One sport that is very good in improving health and fitness is swimming. "The branch of swimming is a water sport that is carried out by moving the body in water, such as using legs and arms so that the body floats on the surface of the water" (Budiningsih, 2010). Swimming is an Aquatic sport that is carried out by moving (floating or lifting) all parts of the body to the surface of the water using the movements of the feet and hands in order to push the body forward. Unlike other sports, swimming is divided into several functions in accordance with the purpose of the sport, namely swimming for rehabilitation sports, recreational sports and performance sports. The achievement of Indonesian swimming sports achievements at the Asian and International levels is an important concern for swimmers themselves such as the government, coaches and athletes. If we review in theory that sports performance is influenced by multifactors consisting of technical and non-technical factors or often also referred to as internal and external factors. Furthermore, Schmolinsky (1983) described the factors supporting peak achievement as there are seven factors consisting of five internal factors and two external factors. Internal factors namely Anthropometrics, physical, engineering, tactics / strategy, psychology. While the external factors are the situation of training and training facilities.

Coaching the maximum achievement in swimming sports must pay attention to the mastery of techniques, both when doing the start or start, swimming techniques, reversal and finish. The start or start in a short distance swimming race is very important and is a concern for coaches and athletes apart from the swim itself. by doing a good start technique it will shorten the swimmer's travel time aside from a good and fast swimming technique. Ernesh W. Maglischow revealed that by improving the start time it could reduce travel time by at least one tenth of a second and the effect of the start time was approximately $25 \%$ of the total time spent in the 20 meter swimming race, $10 \%$ of the total time spent in the 50 meter swimming race, and $5 \%$ of the total time spent in the 100 meter swimming race.

Some of the researchers' observations that deaf swimming athletes during the race a lot of mistakes made by deaf swimming athletes such as jumping before the whistle sounded, and very often the athlete is late in jumping when the whistle is sounded, In addition, in the implementation of the start carried out by athletes do not produce jumps and also the slide is not far ahead. the training model applied by the trainer does not work well, is monotonous and boring as well as the lack of interaction between the coach and the athlete. To overcome this problem it is a must to develop a swimming start training model using video media for deaf children.

The problems that will be examined in this research are as follows: 1) Is there an effect of the exercise model using video media on swimming grabstart skills in deaf children? 2) is there any influence of conventional training models on swimming grabstart skills in deaf children? 3) Are there differences in the effect of the exercise model using video media and conventional training models on swimming grabstart skills in deaf children? In accordance with the formulation of the problem to be studied, the objectives of this study are: 1) to determine the effect of the exercise model using video media on swimming grabstart skills in deaf children? 2) to determine the effect of conventional training models on swimming grabstart skills in deaf children? 3) to find out the different effects of the exercise model using video media and conventional training models on swimming grabstart skills in deaf children?

Swimming sport is one sport that requires the body to do more physical activity in water. Swimming in the Indonesian dictionary is floating and walking on the surface (in) water. according Yeh \& Yeh, (2010) argued that swimming is the healthy and leisure activity suitable for young and old people and it can develop strong figures. Selanjutnya Huang, (2018) swimming is the exercise with low sports injuries, high amount of practice and mild activity. 
Learning is a very interesting topic and is widely discussed by education experts and psychologists, this is because human nature from infancy to adulthood experiences development by learning. learning is an activity or a process to gain knowledge, improve skills, improve behavior, attitudes and strengthen personality. According to Rahyubi, (2012) learning is a life process that is conscious or not must be undertaken by all humans to achieve various kinds of competencies, knowledge, skills and attitudes. whereas according to Coker, (2004) learning is defined as a relatively fixed or permanent change in the ability of each individual to carry out movement skills as a result of an experience or practice.

The process of training is closely related to learning motion. Motion is a characteristic of life. Body movements in this case the motion produced by muscle contraction, allows humans to do various things that support their lives. Motion here is certainly related to skills, which in the broadest sense intends to develop one's mastery of movement skills. According to Wuest \& Charles, (2009) "Motor learning is the study of the study of the acquisition of motor skills as a result of practice and experience. Learning is inferred from changes in performance. "

According to Rink, (2010) learning movement is defined as a change in the circumstances in a person in the form of an increase in skills relatively fixed as a result of training or experience. Meanwhile according to Schmidt \& Timothy, (2011)“ motor learning is a set of processes associated with practice or experience leading to relatively permanent changes in the capability for skilled performance".

The model is a planning plan that is used to describe or explain a process of activities in order to fulfill the expected objectives. According to Thompson, (1994) explains "exercise is a systematic process with the aim of increasing the physical fitness of athletes by performing certain activities". Hadisasmita \& Syarifudin, (1996) states "training is a process of giving patterns, rules and understandings for learning in good conditions". Nossek, (1982) states "training is a process or period of time that lasts for several years until the athlete or athlete reaches the highest standard of performance".

The training models carried out in this study are start reaction, jumping technique, sliding technique, leg movement technique. Technical training is training to improve the movement techniques needed to be able to do the sports that athletes do. According to Harsono, (1988) "Exercise must be in accordance with the circumstances to be achieved with a simple program and not make athletes get bored and carried on while doing". In conducting the Bompa \& Haff, (2009) suggested not to use models or examples of elite athlete techniques, because their techniques might not physiologically meet biomechanical requirements, then here it is recommended to use models that are acceptable to athletes namely models that are suitable for athletes. mechanical and physiological athletes.

According to Kurnia (2001: 24) said the Start is the beginning of a race in various sports including swimming. The role and purpose of the start in the swimming race is very influential on the swimming ability possessed by swimmers. This means that the acquisition of time achieved by a swimmer to finish his finish at a particular swimming number in a swimming race is influenced by the role and ability to start that he has.

According Suharsono, et al (1974) said that "for a swimmer who will take part in the competition, if he cannot start properly means that he will lose, because he will be left behind approximately 1 meter at the start of the race.

In the latest study Morais, Marinho, Arellano and Barbosa (2018) observed that start and turn combined accounted to almost one third of the total race time among finalists of the 100 $\mathrm{m}$ distance events (including all strokes) in the 2016 European Championships, suggesting that coaches and swimmers should dedicate an expressive portion of the training perfecting these actions.

Atho (2010:63) The word media comes from the Latin "medius" which literally means middle, intermediary, or introduction. More specifically, the notion of media in the process of 
teaching and learning tends to be interpreted as graphic, photographic, or electronic tools for expressing, processing and rearranging visual or verbal information.

According to Schramm in Wina Sanjaya the media are classified into complicated, expensive and simple media. Schramm also classifies media according to the ability of coverage, namely (1) wide and simultaneous coverage such as TV, radio and facsimile; (2) limited coverage of the room, such as films, videos, slides, audiotape posters; (3) media for individual learning such as books, modules, computer and telephone learning programs.

In this study using video as an audio-visual media that displays motion and also models of swimming start training techniques. The longer the use of video media increasingly popular in our society. Messages presented in video media can be factual (such as important events, news) or fictitious (such as stories), can be informative, educative or instructional.

Boothroyd in Lani Bunawan (1997: 5) uses the term hearing impairment (Hearing Impairment) to refer to all disturbances in hearing power, regardless of nature, causative factors, and the level / degree of disability. The education expert of the deaf child Daniel Ling (1976) in Edja Sadjaah (2003: 2) argues that "Illiteracy provides the core impact suffered by those concerned namely impaired / impeded language development" According to Murni Winarsih in Ririn (2012: 8) states that hearing impairment is a condition of deficiency or loss of the ability to hear either partly or wholly due to the partial or total deafness of the hearing instrument, so the learner cannot use his hearing aid in daily life. Hearing loss can be classified from $0 \mathrm{~dB}$ to more than $91 \mathrm{~dB}$. according to Jordan, (2001). To put this in context, audiologists categorize hearing based on pure-tone frequencies of 500 to $4000 \mathrm{~Hz}$ and as: normal hearing $(0-20 \mathrm{~dB})$, mild hearing loss $(20-40 \mathrm{~dB})$, moderate hearing loss $(40-60 \mathrm{~dB})$, severe hearing loss $(60-80 \mathrm{~dB})$, and profound hearing loss $(80 \mathrm{~dB}$ or greater.

\section{METHOD}

Based on the problems that will be discussed, this research is quasi-experimental. Hadeli (2002: 67) says that quasi-experimental research is carried out if randomization and control of undesirable factors cannot be carried out. Judging from the location of the study, this research is a type of field experiment research. This study compares one independent variable to the dependent variable. Subject taking techniques in this study using purposive sampling, according to Sugiyono, (2015: 67) Purposive sampling is a sampling technique with certain considerations. Where researchers have considered various kinds both in terms of time, place and even the costs required during research. Research subjects taken in this study are deaf children aged 12 years and over with a classification of $55 \mathrm{~dB}$ moderate hearing loss to $91 \mathrm{~dB}$ or very heavy and can swim breaststroke and $50 \mathrm{~m}$ freestyle totaling 40 people. Consists of 20 experimental groups and 20 control groups.

The test used to measure swimming start skills is the swimming grabstart Skill Test. Data analysis and hypothesis testing using comparative analysis techniques using the Dependent sample t-test, namely Paired sample t-test and Independent sample t-test, namely t-Test: Two-Sample Assuming Equal Variances with a significant level $\alpha=0.05$.

\section{RESULT}

Before being given treatment for a sample of training models using video media, the initial ability tests of swimming grabstart swimming skills are carried out. In the initial test (pre test) of 20 people, the highest score was 68.38 and the lowest score was 32.46, the average score was 51.62. After being given the treatment of 20 samples, the training model using video media was in accordance with the training program, then the final test (post test) of swimming grabstart skills was obtained with the following scores. The highest score is 80.41 and the lowest score is 49.48 , the average score is 65.21 . 
Table 1. Frequency distribution of pre test and post test grabstart swimming skills in the experimental group.

\begin{tabular}{cccccc}
\hline \multirow{2}{*}{$\begin{array}{c}\text { Interval } \\
\text { Class }\end{array}$} & \multicolumn{4}{c}{ Pre Test } & \multicolumn{2}{c}{ Post Test } & \multirow{2}{*}{ category } \\
\cline { 2 - 5 } & Absolute & Relative & Absolute & Relative & \\
\hline$\geq 77,29$ & 0 & 0 & 2 & $10 \%$ & Very well \\
$64,70-77,28$ & 2 & $10 \%$ & 9 & $45 \%$ & Well \\
$52,12-64,69$ & 8 & $40 \%$ & 7 & $35 \%$ & Enough \\
$39,52-52,11$ & 4 & $20 \%$ & 2 & $10 \%$ & Less \\
$\leq 39,51$ & 6 & $30 \%$ & 0 & 0 & Very Less \\
\hline Total & 20 & $100 \%$ & 20 & $100 \%$ & \\
\hline
\end{tabular}

Swimming Grabstart Skills Control Group.

Before being given treatment to a sample of control groups, the initial ability test of swimming grabstart skills is carried out first. In the initial test (pre test) of 20 people, the highest score was 62.40 and the lowest score was 32.46, the average score was 48.32 . After being given the treatment of 20 samples of training, according to the training program given by the trainer, then the final test (post test) of swimming grabstart skills was obtained with the following scores. The highest score is 70.51 and the lowest score is 34.62 , the average score is 53.33 .

Table 2. Frequency distribution of pre test and post test grabstart swimming skills in the control group.

\begin{tabular}{cccccc}
\hline \multirow{2}{*}{$\begin{array}{c}\text { Interval } \\
\text { Class }\end{array}$} & \multicolumn{4}{c}{ Pre Test } & \multicolumn{2}{c}{ Post Test } & \multirow{2}{*}{ Category } \\
\cline { 2 - 5 } & Absolute & Relative & Absolute & Relative & \\
\hline$\geq 64,83$ & 0 & 0 & 5 & $25 \%$ & Very well \\
$55,50-64,82$ & 6 & $30 \%$ & 3 & $15 \%$ & Well \\
$46,16-55,49$ & 6 & $30 \%$ & 7 & $35 \%$ & Enough \\
$36,83-46,15$ & 7 & $35 \%$ & 5 & $25 \%$ & Less \\
$\leq 36,82$ & 1 & $5 \%$ & 0 & 0 & Very Less \\
\hline Total & 20 & $100 \%$ & 20 & $100 \%$ & \\
\hline
\end{tabular}

Hypothesis Testing

This study the researchers applied exercise for 6 (six) weeks in 14 (fourteen) meetings by conducting pre tests, giving treatment and post tests on 20 deaf children as an experimental group and 20 deaf children as a control group.

There is an influence of the exercise model using video media on swimming grabstart skills for deaf children

Based on comparative analysis with the mean difference test formula on the dependent sample using Paired Two Sample for Means, the results of the analysis of the mean difference test ( $\mathrm{t}$ test) are obtained as follows 
Table 3. Summary of Results (T-test) swimming grabstart skills in deaf children in the experimental group

\begin{tabular}{lllllll}
\hline & Mean & & $\mathbf{N}$ & $\begin{array}{c}\mathbf{T} \\
\text { count }\end{array}$ & $\begin{array}{c}\mathbf{T}_{\text {table }} \\
\boldsymbol{\alpha}=\mathbf{0 , 0 5}\end{array}$ & Conclusion \\
\hline $\begin{array}{l}\text { Pre Test } \\
\text { experi }\end{array}$ & $\begin{array}{l}\text { Post Test } \\
\text { experime }\end{array}$ & & & & Significant \\
ment & nt group & 20 & 14,95 & 2,10 & & \\
group & & & & & \\
\hline & 51,05 & 64,94 & & & \\
\hline
\end{tabular}

From the calculation of the experimental group data, because the $T_{\text {count }}(14.95)$ is greater than the $\mathrm{T}_{\text {table }}(2.10)$, there are differences in the results of grabstart exercises using video media for deaf children between pretest and posttest.

There is an influence of the control group on swimming grabstart skills for deaf children. Based on comparative analysis with the mean difference test formula on the dependent sample using Paired Two Sample for Means, the results of the analysis of the mean difference test ( $\mathrm{t}$ test) are obtained as follows

Table 4. Summary of Results (T-test) swimming grabstart skills for deaf children in the control group

\begin{tabular}{llllll}
\hline \multicolumn{2}{c}{ Mean } & $\mathbf{N}$ & $\mathrm{T}_{\text {count }}$ & $\begin{array}{c}\mathbf{T}_{\text {table }} \\
\boldsymbol{\alpha}=\mathbf{0 , 0 5}\end{array}$ & Conclusion \\
\hline $\begin{array}{llllll}\text { Pre } \\
\text { control group }\end{array}$ & $\begin{array}{l}\text { Post } \\
\text { control } \\
\text { group }\end{array}$ & 20 & 4,47 & 2,10 & \\
\cline { 1 - 2 } 47,89 & 52,69 & & & & \\
\hline
\end{tabular}

From the calculation of the control group swimming pool start skills data, it is found that the $\mathrm{T}_{\text {count }}(4.47)$ is greater than the $\mathrm{T}_{\text {table }}(2.10)$, so there is a difference in the control swimming pool start skill data between the pretest and posttest.

There is a difference in the effect of the exercise model using video media and the control group on swimming grabstart skills in deaf children

Based on comparative analysis with the mean different test formula on Independent Samples using t-Test: Two-Sample Assuming Equal Variances conducted, the results of the analysis of the mean different test ( $t$ test) are obtained as follows

Table 5. Summary of Results (T test) Post Test of swimming grabstart skills for deaf children in the experimental and control groups

\begin{tabular}{llllll}
\hline Mean & & $\mathrm{N}$ & $\begin{array}{l}\mathrm{T} \\
\text { count }\end{array}$ & $\begin{array}{l}\mathrm{T}_{\text {table }} \\
\alpha=0,05\end{array}$ & Conclusion \\
\hline $\begin{array}{l}\text { Post Test } \\
\text { experiment } \\
\text { group }\end{array}$ & $\begin{array}{l}\text { Post Test } \\
\text { control } \\
\text { group }\end{array}$ & & & & Significant \\
& 52,69 & 3,82 & 2,02 & \\
\hline
\end{tabular}

From the calculation of the swimming pool start skill data of the experimental group and the control group, it was found that the Tcount (3.82) was greater than the Ttable (2.02), so there was a significant difference between the experimental and control groups furthermore it is 
necessary to know the magnitude of the increase in swimming start skills of deaf children, in this study the researchers used a gain score test. The data gain scores are as follows:

Table 6 : Gain Score

\begin{tabular}{ccccc}
\hline Criteria & Experiment & Percentage & Control & Percentage \\
\hline Low & 1 & $5 \%$ & 13 & $65 \%$ \\
medium & 17 & $85 \%$ & 6 & $30 \%$ \\
High & 2 & $10 \%$ & 1 & $5 \%$ \\
\hline
\end{tabular}

It can be described that the start swimming skills of the experimental group included in the High category 2 (two) subjects with a percentage of $10 \%$, the medium category 17 (seventeen) subjects with a percentage of $85 \%$ and the low category 1 (one) subject with a percentage of $5 \%$. As for the start swimming skills of the control group that belongs to the High category of 1 (one) subject with a percentage of 5\%, the medium category is 6 (six) subjects with a percentage of $30 \%$ and the low category is 13 (thirteen) subjects with a percentage of $65 \%$.

Figure 1: Bar chart Gain Score

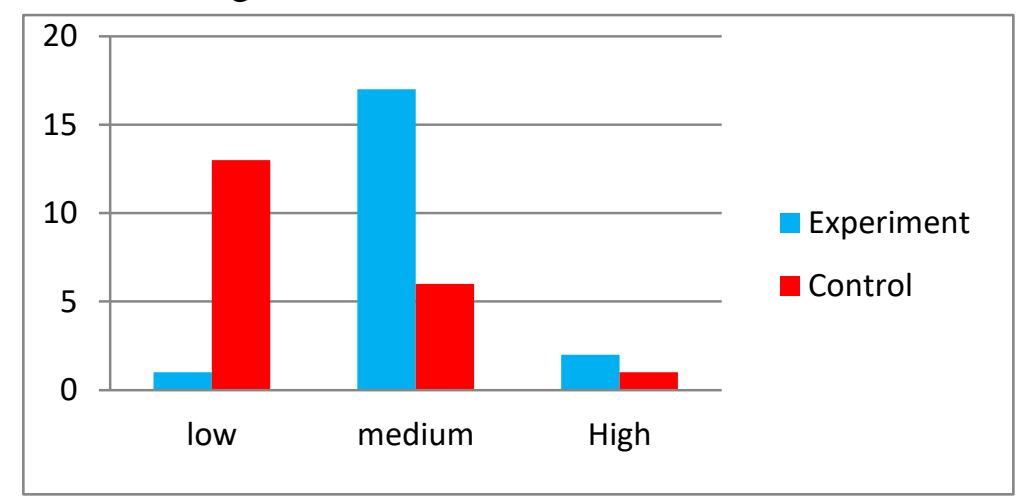

Thus it can be concluded that, the swimming start skills for deaf children in the experimental group or the group treated using grabstart training model of swimming using video media is better than the swimming start skills for deaf children in the control group / comparison group.

\section{CONCLUSION}

Based on the results of the needs analysis, assessment of experts, field trials and discussion of product development, it can be concluded that:

1. There is an effect of the exercise model using video media on grab start swimming skills in deaf children from an average value of 51.05 to 64.94 with $\mathrm{T}_{\text {count }}=14.93>\mathrm{T}_{\text {table }}=2.10$.

2. There is an influence of the control group on grab start swimming skills in deaf children from an average value of 47.89 to 52.69 with $\mathrm{T}_{\text {count }}=4.47>\mathrm{T}_{\text {table }}=2.10$.

3. There is a difference between the effect of the exercise model using video media with a control group with $\mathrm{T}_{\text {count }}=3.82>\mathrm{T}_{\text {table }}=2.02$. Based on the increase in the average value of the experimental group pre-test of 51.05 to post-test 64.94 increased 13.89 or $27.21 \%$ in the control group with an average pre-test value of 47.89 to post-test 52.69 increased 4.8 or $10.02 \%$. thus the experimental group was more effective than the control group in improving swimming grabstart skills in deaf children. 


\section{REFERENCE}

Atho. Muzdhar. Media Pembelajaran. Jakarta: PT Raja Grafindo Persada. 2010

Bompa, T., \& Haff, G. G. (2009). Periodization Theory And Metodolgy Of Training. Human Kinetics

Bompa, T., \& Haff, G. G. (2009). Periodization Theory And Metodolgy Of Training. Human Kinetics

Budiningsih, A. (2010). Berenang Gaya Bebas. Pura Barutama.

Coker, C. A. (2004). Motor learning and Control Practitioners. McGraw Hill.

Ernest W.Maglischow. swimming Event Faster. California May Field Publishing Company.1993

F.Ririn, Meningkatkan Kemampuan Artikulasi Anak Tunarungu Menggunakan Metode Drill. Yogyakarta, 2012

Hadeli .2002. Metode Penelitian Kependidikan. Padang : Baitul Hikmah Pers

Hadisasmita., Y., \& Syarifudin. (1996). Ilmu Kepelatihan Dasar. Departemen Pendidikandan Kebudayaan, Direktorat Jendral Pendidikan Tinggi, Proyek PendidikTenaga Akademik

Harsono. (1988). Coaching dan Aspek-Aspek Psikologis dalam Coaching. Lembaga Pendidikan Tenaga Kependidikan.

Huang, J. (2001). Construction and Validation of Swimming Constraint Factors of MiddleAged or Seniors in Swimming Pools of Public Universities. 2018, 14

Jordan, J. M. (2001). CISS and the International Paralympic Committee. In J. M. Lovett, J. Eickman, \& T. Giansanti (Eds.),CISS 2001: Comite' International des Sports des Sourds a Review (pp. 54-57). Redditch, UK: Red Lizard Ltd (Journal of Sports Sciences)

Kementrian Negera Pemuda dan Olahraga Republik Indonesia nomor 3 tahun 2005 tentang Sistem Keolahragaan Nasional. Jakarta Presiden Republik Indonesia.

Kurnia, Dadeng. 2001. Teknik dasar dan lanjutan renang. Jakarta: PBPRSI

Lani Bunawan, 1997. Komunikasi Total. Jakarta: Depdikbud Direktorat Jendral Pendidikan Tinggi Proyek Tenaga Akademik

Morais, J.E., Marinho, D.A., Arellano, R., Barbosa, T.M. (2018) Start and turn performances of elite sprinters at the 2016 European Championships in swimming. Sports Biomechanics. doi: 10.1080/14763141.2018.1435713 (European Journal of Sport Science)

Nossek, J. (1982). Teori Umum Latihan. Pan African Press.

Rahyubi, H. (2012). Teori-teori Belajar dan aplikasi Pembelajaran Motorik. Referens

Rink, J. E. (2010). Teaching Physical Education forLearning, 6th Edition. McGraw-Hill Co., Inc.

Sadjaah, Edja. (2005). Pendidikan Bahasa Bagi Anak gangguan Pendengaran dalam Keluarga. Jakarta: Depdiknas Dirjend. Pend. Tinggi Direktorat Pembinaan Pend.Tenaga Kependidikan dan Ketenagaan Perguruan Tinggi. (Journal of Early Childhood Education)

Schmidt, L. R. ., \& Timothy, D. (2011). Motor Control And Learning 5th. Human Kinetics Books

Schmolinsky, G. (1983). Track and Field. portverlag

Suharsono, dkk. Renang Bagi Pemula. Jakarta : Dirjen Olahraga Dan Pemuda. Depdikbud. 1974

Thompson, P. J. L. (1994). Introduction To Coaching Theory. IAAF.

Wuest \& Charles. (2009). Physical Education, Exercise Science, and Sport. 16thEdition. McGraw-Hill Co, Inc

Yeh, \& Yeh. (2010). Study on value of leisure swimming. Leisure and Holistic Wellness. 
